\title{
A STUDY OF SACRALISATION OF FIFTH LUMBAR VERTEBRA IN SOUTH INDIAN POPULATION
}

\section{Drakshayini. B. Kokati, Shubha Nivargi *.}

Assistant Professor, Department of Anatomy, Karanataka Institute of Medical Sciences, Hubli, Karnataka state, India.

\section{ABSTRACT}

Background: Among the congenital anomalies of the spine LSTV- Lumbosacral Transitional Vertebra is the most common anomaly which is associated with the complaint of low back pain in modern era. LSTVs include sacralisation of the lowermost lumbar vertebra as well as lumbarisation of uppermost sacral segment.

Aims and Objectives: The present study was done to know the incidence of sacralisation of fifth lumbar vertebra in South Indian Population.

Materials and Methods: The present study includes 70 dry adult human sacra of both sexes. Note was made on the number of sacral segments in each sacrum. Sacrum with six elements and five sacral foramina were identified and studied.

Results and Conclusion: In the present study sacralisation was observed in 8 sacra. The knowledge of sacralisation of fifth lumbar vertebra is important to clinicians in the diagnosis and treatment of low back pain.

KEY WORDS: Sacralisation, Vertebra, Low backpain.

Address for Correspondence: Dr. Shubha Nivargi, Assistant Professor, Department of Anatomy, Karanataka Institute of Medical Sciences, Hubli, Karnataka state, India.

E-Mail: shubhanivargi@yahoo.com

Access this Article online

Quick Response code

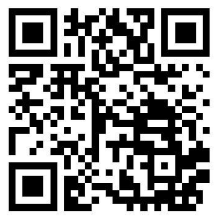

DOI: $10.16965 /$ ijar.2017.536

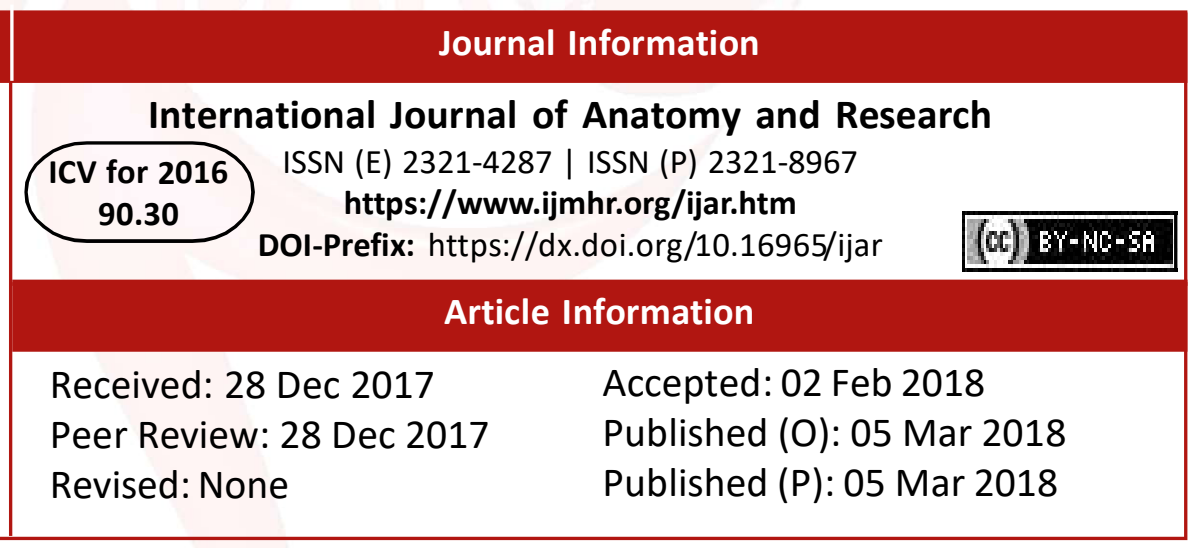

\section{INTRODUCTION}

In modern era about $80 \%$ of general population complains of low back pain [1]. Back pain may be contributed by congenital anomalies of the spine along with various other causes. Among the congenital anomalies of the spine, LSTVLumbosacral Transitional Vertebra is most common anomaly which is associated with complaint of low back pain. LSTVs include sacralisation of lowermost lumbar vertebra as well as lumbarisation of uppermost sacral segment. LSTVs are seen with a reported prevalence of $4 \%-30 \%$ [2]. Lumbosacral transitional vertebrae (LSTV) are congenital anomalies of the lumbosacral region, observed for the first time by Bertolotti in 1917 [3]. These occur due to defect in the segmentation during development. In sacralisation the transverse process of fifth lumbar vertebra becomes larger than the normal on one side or on both sides and fuses with the sacrum or ilium or both. Thus such sacra show six elements and five sacral foramina. Sacralisation can be unilateral or bilateral. It can also be complete and incomplete. In complete sacralisation there is complete bony union between abnormal transverse process of fifth lumbar vertebra and the sacrum, where as in incomplete sacralisation there is a well defined joint line between the transverse process and 
the sacrum. According to Bertolotti these abnormal vertebrae may produce low back pain due to arthritic changes occurring at the site of false articulation [3]. Low back pain may also be due to chronic faulty biomechanics in these cases [4].

Aims and objectives: The present study was done to know the incidence of sacralisation of fifth lumbar vertebra in South Indian Population.

\section{MATERIALS AND METHODS}

The present study includes 70 dry adult human sacra of both sexes obtained during undergraduate teaching in the department of anatomy in our institution. Sacra which were deviating from the definition of sacralisation were excluded from the study. Note was made on the number of sacral segments in each sacrum to identify sacralisation. Sacrum with six elements and five sacral formina were identified and studied. Bony fusion of the transverse process and vertebral body of sacralised bones were observed. It was also noted whether bony fusion was unilateral and bilateral in these bones.

\section{RESULTS AND DISCUSSION}

Fig. 1: Sacra showing sacralisation of lumbar vertebra.

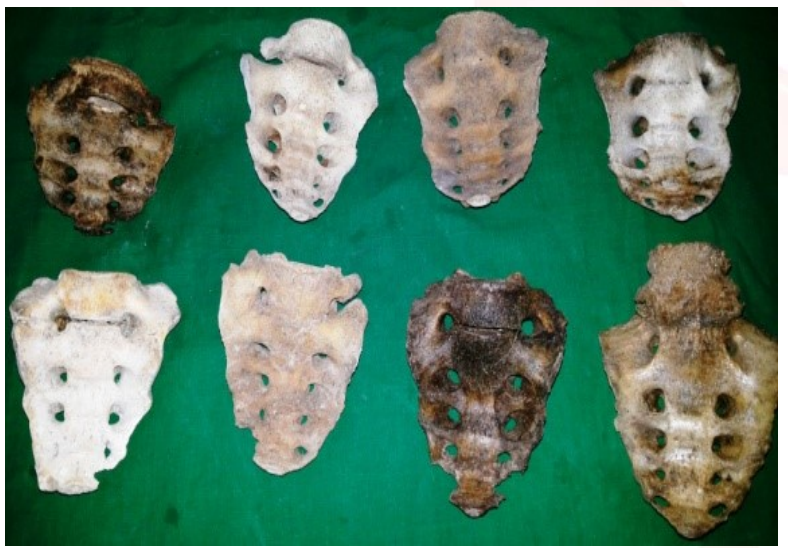

Fig. 2: Sacra showing bilateral sacralisation. $1^{\text {st }}$ and $4^{\text {th }}$ sacra - vertebral body not fused.

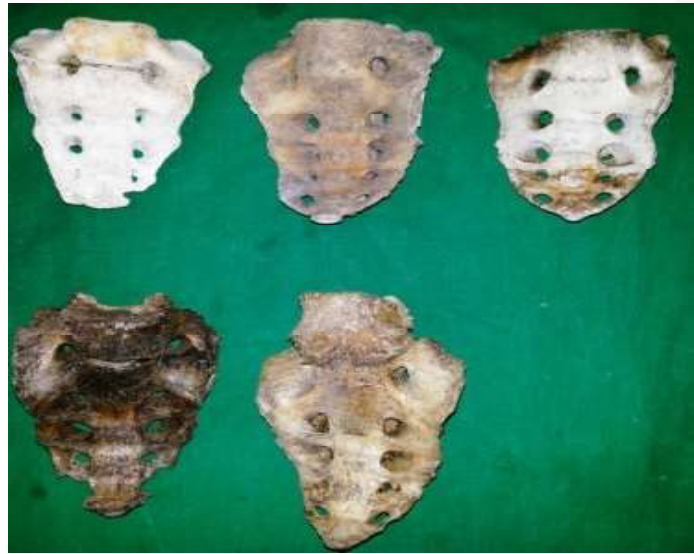

Fig. 3: Sacra showing unilateral sacralisation.

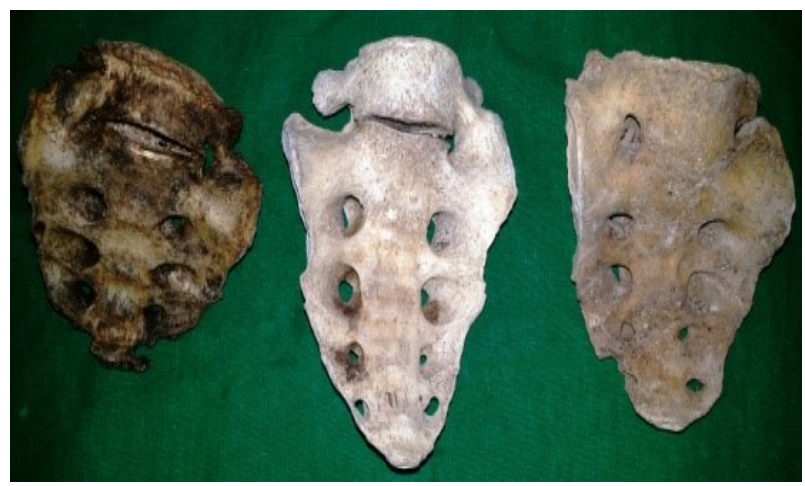

$1^{\text {st }}$ - Left side transverse process partially fused; vertebral body not fused.

$2^{\text {nd }}-$ right side transverse process not fused; vertebral body not fused.

$3^{\text {rd }}$ - left side transverse process not fused; vertebral body completely fused.

In the present study out of 70 dry sacra, 8 $(11.42 \%)$ were seen to have sacralisation . Out of these 8 , bilateral sacralisation was observed in 5 sacra (7.14\%) and unilateral sacralisation was observed in 3 sacra (4.28\%).

Table 1: Comparison of incidence of sacralisation of lumbar vertebra.

\begin{tabular}{|c|c|c|}
\hline Authors & Population & Incidence \\
\hline Kubavat et al [4] & Indians -Gujarat & $11.10 \%$ \\
\hline Karan et al [5] & Indians- Maharastra & $6.60 \%$ \\
\hline Moore \& Illinois [6] & Americans & $3.30 \%$ \\
\hline Brailsford [7] & Natives of Britain & $8.10 \%$ \\
\hline Sangeeta [8] & Indians- Jammu & Single case report \\
\hline Present study & Indians- Karnataka & $11.42 \%$ \\
\hline
\end{tabular}

The occurrence of lumbosacral transitional vertebra is linked to its embryological development and osteological defects. Embryologically, the vertebra receives contribution from caudal half of one sclerotome and from the cranial half of succeeding sclerotome [9]. The clinical significance of sacralisation of lumbar vertebra has been associated with neurological deficit \& low back pain. The complications of sacralization of 5th lumbar vertebra which cause low back pain, spinal or radicular pain are due to pressure on nerves or nerve trunks, ligamentous strain around the sacralization, compression of soft tissues between bony joints, by arthritis if a joint is present, by a bursitis if a bursa is present [5]. In this condition as intervertebral disc space netweem L5 and S1 is narrow and thin there are higher chances of disc herniation, sciatic pain. As the pattern of sacralisation varies from 
person to person, the signs and symptoms also vary in severity and intensity. This condition is linked with problems in biomechanics and affects the movements and posture control. Unilateral and incomplete variety of sacralisation can make the working of spine difficult. Subsequently lumbar scoliosis can develop. In females with sacrali-sation of 5 th lumbar vertebra, pelvic mobility is reduced during labour.

\section{CONCLUSION}

Knowledge of sacralisation is important for Radiologists for accurate numerical identification of vertebral segments on various imaging techniques; for orthopaedic and neurosurgeons working in this region to avoid surgery at an incorrect level; for anaesthetitsts as the land mark used for needle insertion for spinal anaesthesia and lumbar puncture is affected. The intercrestal line normally corresponds with the level L4/L5. Sacralisation of 5 th lumbar vertebra affects the position of the intercrestal line (the line connecting the highest points of the iliac crests, also called 'Tuffier's line'), and on the location of the conus medullaris. The knowledge of present study is also required to forensic experts as tool for stature estimation and identification of skeletal remains, provided antemortem records are available and this confirms identity. Clinically the present study emphasizes its relevance in incorrect numbering during the planning of spinal surgery and prevention of serious consequences.

\section{Conflicts of Interests: None}

\section{REFERENCES}

[1]. Dullerud R: Diagnostic imaging in lumbago and sciatica . Ugeskr Laeger 1999;161:299-303.

[2]. Bron JL, Van Royen BJ, Wuisman PI. The clinical significance of lumbosacral transitional anomalies. Acta Orthop Belg 2007;73:687-95

[3]. Bertolotti M Contributto alla conoscenza dei vici di differenzarione regionale del rachide con speciale riguards all asimilazzione sacrale della v. lombare. Radiologique Medica 1917;4:113-44.

[4]. Kubavat D, Nagar SK ,Malukar O, Trivedi D ,Shrimankar P, Patil S. National Journal Medical Research.2012;2(2):211-213.

[5]. Karan B K, Manisha B R. sacralisation of lumbar vertabra. Indian Journal of Basic \& Applied Medical Research. 2013;6(2):510-514.

[6]. Moore BH, Illinois C. Sacralization of the fifth lumbar vertebra. J Bone Joint Surg 1925;7:271-278.

[7]. Brailsford JF. Deformities of the lumbosacral region of the spine. Brit J Surg 1928;16:562-627.

[8]. Sangeeta W. Sacralisation of lumbar vertebrae. Int J Anat Res. 2014;2(2):386-89.

[9]. Keith. L. Moore,T.V.N.Persaud, The Developing human, clinically oriented embryology Skeletal system.8th edition, published by saunders, Elsevier,Philadelphia, 2008:344-346.

\author{
How to cite this article: \\ Drakshayini. B. Kokati, Shubha Nivargi. A STUDY OF \\ SACRALISATION OF FIFTH LUMBAR VERTEBRA IN SOUTH INDIAN \\ POPULATION. Int J Anat Res 2018;6(1.3):5004-5006. DOI: \\ 10.16965/ijar.2017.536
}

